\title{
Examining the overarching factors of clients' loyalty based on the mobile insurance typology
}

\begin{tabular}{|c|c|}
\hline \multicolumn{2}{|c|}{$\begin{array}{l}\text { Authors: } \\
\text { Enock M. Ampaw }{ }^{1} \text { (D) } \\
\text { Junwu Chai }{ }^{1,2} \text { (D) } \\
\text { Joseph Frempong }{ }^{1,2} \text { (D) }\end{array}$} \\
\hline \multicolumn{2}{|c|}{$\begin{array}{l}\text { Affiliations: } \\
{ }^{1} \text { School of Management and } \\
\text { Economics, University of } \\
\text { Electronic Science and } \\
\text { Technology of China, } \\
\text { Chengdu, China }\end{array}$} \\
\hline \multicolumn{2}{|c|}{$\begin{array}{l}{ }^{2} \text { Center for West African } \\
\text { Studies, University of } \\
\text { Electronic Science and } \\
\text { Technology of China, } \\
\text { Chengdu, China }\end{array}$} \\
\hline \multicolumn{2}{|c|}{$\begin{array}{l}\text { Corresponding author: } \\
\text { Junwu Chai, } \\
\text { chaijw@uestc.edu.cn }\end{array}$} \\
\hline \multicolumn{2}{|c|}{$\begin{array}{l}\text { Dates: } \\
\text { Received: } 02 \text { Jan. } 2019 \\
\text { Accepted: } 26 \text { Apr. } 2019 \\
\text { Published: } 15 \text { Aug. } 2019\end{array}$} \\
\hline \multicolumn{2}{|c|}{$\begin{array}{l}\text { How to cite this article: } \\
\text { Ampaw, E. M., Chai, J., \& } \\
\text { Frempong, J. (2019). } \\
\text { Examining the overarching } \\
\text { factors of clients' loyalty } \\
\text { based on the mobile } \\
\text { insurance typology. South } \\
\text { African Journal of Business } \\
\text { Management } 50(1), \text { a1418. } \\
\text { https://doi.org/10.4102/ } \\
\text { sajbm.v50i1.1418 }\end{array}$} \\
\hline \multicolumn{2}{|c|}{$\begin{array}{l}\text { Copyright: } \\
\text { (C) 2019. The Authors. } \\
\text { Licensee: AOSIS. This work } \\
\text { is licensed under the } \\
\text { Creative Commons } \\
\text { Attribution License. }\end{array}$} \\
\hline \multicolumn{2}{|l|}{ Read online: } \\
\hline 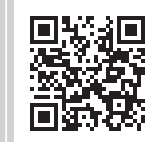 & $\begin{array}{l}\text { Scan this QR } \\
\text { code with your } \\
\text { smart phone or } \\
\text { mobile device } \\
\text { to read online. }\end{array}$ \\
\hline
\end{tabular}

Background: The mobile insurance industry plays a crucial role in the insurance ecosystem of developing countries, yet the overarching factors that impinge on and shape clients' behavioural intentions towards service providers have not been given the necessary attention they deserve.

Objectives: This study explores the role of corporate identity, clients' satisfaction, Service Quality (SERQUAL) and institutional-based trust in shaping clients' loyalty (CL) towards mobile insurance (M-insurance) service providers.

Method: Structural equation modelling (SEM) was used to analyse a total of 334 questionnaires obtained from clients of selected M-insurance service points in Accra, Ghana.

Results: Our results indicate that SERQUAL, institutional-based trust, satisfaction and corporate identity, corroboratively, impact positively on CL within the M-insurance ecosystem, albeit in varied proportions. The results also demonstrate a high degree of causality among SERQUAL, institutional-based trust and corporate identity.

Conclusion: SERQUAL has both direct and indirect significant positive relationships with CL. Thus, in order for M-insurance service providers to attract and retain clients, the former must pay a great deal of attention to SERQUAL owing to its striking halo effects.

Keywords: Mobile insurance; microinsurance; service quality; SERQUAL; loyalty; mobile network operators; institutional-based trust; Ghana.

\section{Introduction}

The inevitable nature of livelihood risk associated with the household, and the general business environment at large has occasioned the need for insurance cover to enable the insured party to claim for indemnity or to provide a financial cushion in the face of a catastrophe. Through insurance provisions, some policyholders are made financially whole after an unexpected loss. In general, insurance can be defined as any financial market product designed to provide financial cover, or as a risk transfer service where an entity within the business continuum assumes to bear the uncertainty of another entity through a mutual agreement of regular premium payment. It is an important mechanism for managing uncertainties and vulnerabilities of those insured (Ndurukia et al., 2017a). However, the dualism of low-income levels and high premiums offered by the general insurance ecosystem in developing and emerging economies has excluded a chunk of the populace from insurance uptake of any kind. It is against this backdrop that microinsurance models were birthed to deepen financial inclusion. Mobile insurance (M-insurance; mobileenabled insurance, credit and savings platforms) similar to other microinsurance models was developed purposely to ameliorate household shocks and financial risk of low-income earners (Camilo Tellez \& Zetterli, 2012; Churchill, 2006; Global System for Mobile Communications [GSMA], 2014, 2017; Giesbert, Steiner, \& Bendig, 2011).

Empirical studies opine that it alleviates and combats extreme poverty and hunger through the provision of products such as agriculture, life and funeral cover to its niche-focused economically underprivileged group (Chummum, 2012). Thus, the evolving trend of microinsurance is geared in support of business establishment, growth, social improvement and safety cover for people within low-income brackets. Even though the main objective for the creation of microinsurance was to widen the insurance net by raking in the low-income group who are the majority in developing and emerging economies, there exist a plethora of challenges to meet this objective because of technological limitations and the uneven distribution of traditional microinsurance service providers (GSMA, 2014; Gikonyo, 2012; Tellez, 2013). The emergence of mobile network operators (MNOs) and successes chalked up in the telecommunication technology infrastructure have, however, given a new impetus to the microinsurance landscape. The MNOs in developing countries 
are now offering insurance services, and other innovationdriven services to encourage the wider general public on insurance uptakes. Studies on the effects of mobile technology in the growth of insurance in Kenya indicate that technological advancement in mobile phone correlates positively with microinsurance uptake (Gikonyo, 2012; Tellez, 2013).

Mobile insurance (M-insurance) through its unique Abovethe-Line (ATL), ${ }^{1}$ Below-the-line (BTL) ${ }^{2}$ and 360-marketing campaign, ${ }^{3}$ advertising strategies by MNOs since its inception has whipped up insurance interest and created unparalleled insurance awareness among low-income earners (Prashad, Saunders, \& Aparna, 2013; Zetterli, 2013). The MNOs are now offering $\mathrm{M}$-insurance services in countries such as Ghana, Philippines, Uganda, Kenya, Tanzania, Zimbabwe, among others (Tran, 2013; Leach, 2010; Leach \& Ncube, 2014). They have revolutionised and changed the 'face' of the microinsurance industry as a result of unforgiven competitions, fuelled by cutting edge products offered by the individual service providers (Camilo Tellez, 2013; Tellez \& Zetterli, 2012). Thus, clients' loyalty (CL) cannot be divorced from business continuity.

Furthermore, the market for microinsurance in most developing countries is relatively limited and therefore, the need for innovative strategies geared towards clients' satisfaction and loyalty is of the essence (GSMA, 2017). There are studies on the operations of the microinsurance industry in some developing countries, but not with explicit examination of factors that impact clients' satisfaction and loyalty within the realms of M-insurance to the best of our knowledge. Giesbert and Steimer (2011) studied the perception of microinsurance in southern Ghana and concluded that peoples' perception of microinsurance is based on incomplete information and intuition. Ndurukia et al. (2017) conducted a study on the determinants of microinsurance services in Kenya, and established that access to credit, price and risk exposure are the main drivers of microinsurance uptake in Kenya.

Again, a study carried out by the German Federal Ministry for Economic Cooperation and Development at the behest of the National Insurance Commission (NIC) on M-insurance and risk management in Ghana (2015) shows that $60 \%$ of lives were covered by the M-insurance model. The study further advances that the M-insurance model is more economically viable than its alternative models (Mobile Insurance and Risk Management in Ghana, 2015).

In a related research on the landscape of microinsurance in Ghana (National Insurance Commission, 2015), ostensibly on

1.ATL is the application of mass media to build brands and to reach out to target customers. It focuses on mass penetration. Radio, TV, print advertisement, and Internet are the common channels of ATL as a marketing drive.

2.BTL is more niche focused, one-on-one, and specific in nature. It encapsulates the distribution of brochures, pamphlets, stickers, banners, placards and others, aimed at specific penetration.

3.360-marketing campaign is also known as Through-The-Line (TTL) advertising; and thus involves a holistic and all-inclusive approach for customer 'hunt'. It involves the integration of ATL and BTL for optimal results. It encompasses outbound mails, customer communication, social media, Search Engine Optimization, Content and Website. the supply and demand for microinsurance, it was revealed that an excess of 7496212 lives and properties were insured in 2014 by the microinsurance industry alone with product offerings such as personal accident, credit-life, hospitalisation, agriculture and endowment policies. The study further posits that the main distribution channels of these products are MNOs, microfinance companies, commissioned staff, and agents, among others (National Insurance Commission, 2015). Ronoh (2012) in his seminal report highlighted the influential role of mobile money transfer and the M-BIMA platform in deepening financial inclusion in Kenya and its antecedent's opportunities for insurers.

A fundamental knowledge gap, however, exists in the existing literature on the overarching factors of $\mathrm{CL}$ and continuous service utilisation within the M-insurance ecosystem. Therefore, this study with evidence from a Ghanaian perspective intends to fill this yawning gap in the literature.

Addressing this gap in the literature is fundamental and crucial for M-insurance industry players to stay afloat in the present regime of intense industrial rivalry. In order to create long-lasting relationships with clients, industry players must provide services and products that meet clients' perceived expectation. Studies show that it costs five times more to acquire new customers than to retain them (Bhattacherjee, 2001; Chen \& Myagmarsuren, 2011; Vatanasombut, Igbaria, Stylianou, \& Rodgers, 2008). Thus, the implications of this study will serve as precursor and policy guide to players within the M-insurance service industry in designing products and services strategies that will enhance CL in the present market situation characterised by an avalanche of competition. Also, the article seeks to generate topics for dialogue that may provoke interest and discussion on drivers of CL within the framework of insurance in general. Although the focus of the study is on Ghana, the commonalities in terms of socio-economic features of countries with remarkable presence of M-insurance services make our findings transferable.

The remainder of the article is partitioned into: context of the study: M-insurance landscape Ghana; theoretical background, hypotheses development and conceptual framework; materials and methods; results and discussion; and lastly, conclusion and implications

\section{Context of the study: M-insurance typology in Ghana}

$\mathrm{M}$-insurance in a generic sense is any microinsurance product whose marketing involves the MNOs as the conduit in delivering some components of an insurance value chain to prospective clients. The M-insurance market has been scaling up globally with a myriad of new products being rolled out annually. It is estimated that as of June 2016, there were over a $100 \mathrm{M}$-insurance services, and 52.7 million policies issued (denoting a whopping 263\%, annualised growth) across 30 countries globally - powered by the disruptive technologies and innovations of MNOs (GSMA, 2014, 2016). 
Arguably, its intended purpose of creating a niche market to amplify financial inclusion ostensibly for demographics within low-income brackets is being met. It is evidenced that there has been a global pattern of financial liberation and economic empowerment in regions of socio-economic commonalities (such as Africa, Asia and Latin America) where mobile-enabled insurance, credit and savings products are visibly and ubiquitously present. The composition of insurance services offered by the M-insurance industry range from life, health and accident to agriculture (GSMA, 2016).

The unique presence of microfinance schemes in the aforementioned geographical settings is against the backdrop of unmet conditions attached to the product offerings of general insurance service providers by a chunk of the populace. The M-insurance model, however, is appealing and attractive to the underserved and the low-income clusters of the society. It is designed to accommodate the unique socioeconomic characteristics of these vulnerable demographics. Relative to orthodox insurance product offerings, the M-insurance products have a peculiarly low distribution cost, and thus make it feasible to spread financial services to a chunk of the populace in order to manage their household shocks and financial risk (GSMA, 2016). India and Bangladesh are two countries outside the African enclave with huge footprints of M-insurance services (GSMA, 2014).

According to (National Communication Authority, 2015) report, Ghana has a mobile network penetration rate of approximately $115 \%$; and the country is adjudged as one of the most promising and vibrant mobile markets in African. There are six licensee MNOs in Ghana - Mobile Telephone Network (MTN) (45.6\% market share), Vodafone (23\% market share), Tigo (13.85\%), Airtel (12.4\%), Glo (4.8\%) and Expresso (0.4\%) (Mobile Insurance and Risk Management in Ghana, 2015).

The microinsurance industry in Ghana assumed a propitious dimension in the wake of Tigo's and MTN's launch of M-insurance products in 2010 and 2011, respectively. M-insurance is an innovative insurance delivery system through which the MNOs market insurance products to the wider general public. It plays overarching roles within the Ghanaian and similar developing economies' microinsurance ecosystem as it is estimated that $60 \%$ of lives were insured (in Ghana) via M-insurance in 2014 alone. The M-insurance models are twofold, namely, the strategic model ${ }^{4}$ and the transactional model. ${ }^{5}$ In a strategic model, the insured clients recognise the insurance products to be owned by the MNOs because of the product's implementation, branding, advertisement and marketing mechanism (Mobile Insurance and Risk Management in Ghana, 2015; Tellez \& Zetterli, 2012).

\footnotetext{
4.Products under the strategic model of $\mathrm{M}$-insurance are more viable and propitious in Ghana than its counterpart. The TSPs, MNOs, and Financial Institutions are responsible for products development under this regime. These institutions are in turn regulated by National Insurance Commission (NIC) and Bank of Ghana (BoG) to ensure clients' protection and products viability.

5.The MNOs provide infrastructure and transactional platforms to 'traditional' insurance processes. Thus, the MNOs play a passive role such as facilitating premium collection and claim payment. A classic example is the Safaricom of Kilimo Salama weather-index insurance product in Kenya, where the MNO's singular function is to serve as a conduit for premium and claim payments for insurance function is to serve as a conduit for premium and claim payments for insurance
uptake. Owing to the embryonic stage of mobile money in Ghana, the transactional uptake. Owing to the embryonic stage
model is relatively not prominent.
}

Strategic M-insurance products are grouped into two: loyalty (otherwise known as Freemium) and paid products. Under the loyalty products option, MNOs pay the premium and offer the insurance to subscribers as a monthly freebie, aiming at incentivising subscribers to increase the average revenue per user (ARPU), and secondly, to eschew a possible switch to a competitor. Subscribers are, however, eligible for the monthly insurance coverage only if a top-up to a certain threshold is made.

Under the paid products regime, subscribers personally pay for the insurance through mobile money or direct payment (airtime). Automatic payment is made if there are sufficient funds in the subscribers' M-wallet or airtime (Mobile Insurance and Risk Management in Ghana, 2015).

Studies indicate that there are an estimated 2.7 million M-insurance policyholders, and three service providers (MNOs) - Tigo, MTN and Airtel: are presently operating in Ghana. Also, there are three insurers in the Ghanaian M-insurance market - Prudential, Enterprise Life and Unique Trust (UT) Life - and three Technical Service Providers (TSP) namely, Barmore Insurance Marketing Association (BIMA), Mobile Financial Services (MFS) Africa and MicroEnsure (Mobile Insurance and Risk Management in Ghana, 2015; Tellez \& Zetterli, 2012; Tellez, 2013). Relative to other enclaves, sub-Saharan Africa is extremely active in M-insurance provision (see Table 1) because of the financially inclusive nature of the model. The current M-insurance products in Ghana are predominantly, hospitalisation, funeral, life, personal accident and property covers (see Table 2), with monthly premiums payment from mobile wallets or airtime deduction (Mobile Insurance and Risk Management in Ghana, 2015; Ndurukia et al., 2017).

The apparent socio-economic commonalities within the enclaves with huge footprints of M-insurance, thus, make the findings our study transferable.

\section{Theoretical background, hypotheses development and conceptual framework Clients' loyalty}

In order to have a competitive edge in a highly charged competitive environment such as the M-insurance market, industry players must constantly pursue top notch strategic plans aiming at securing CL. In other words, service providers must innovatively differentiate themselves from rivals; and

TABLE 1: Mobile money industry matrix.

\begin{tabular}{lccc}
\hline Variable & Ghana & Sub-Saharan Africa & Worldwide \\
\hline Mobile money service providers & 5 & 135 & 225 \\
Mobile money account holders & $>5000000$ & 146000000 & 299000000 \\
Ratio of active mobile money (\%) & 40 & 42.4 & 34.6 \\
Mobile money agents & - & - & 2260000 \\
\hline
\end{tabular}

Source: Global System for Mobile Communications (GSMA). (2015). State of mobile money in Sub-Saharan Africa. GSMA Publication. Retrieved from https://www.gsma.com/

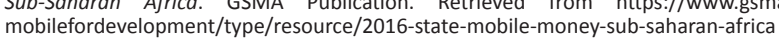


TABLE 2: M-insurance products offerings and service providers in Ghana.

\begin{tabular}{|c|c|c|c|c|c|c|}
\hline MNOs & Insurers & Technical service providers & Banks & Product category & Indemnity policies & Year of inception \\
\hline Tigo & Prudential & BIMA & Ecobank, UBA and ADB & Paid & Funeral & 2010 \\
\hline Tigo & Prudential & BIMA & Ecobank, UBA and ADB & Paid & Health & 2013 \\
\hline Tigo & Prudential & BIMA & Ecobank, UBA and ADB & Loyalty & Funeral & 2010 \\
\hline MTN & UT life & MFS Africa & Fidelity & Paid & Funeral & 2011 \\
\hline Airtel & Enterprise Life & MicroEnsure & Fidelity and Ecobank & Loyalty & Life, Health, Disability & 2014 \\
\hline Airtel & Enterprise Life & MicroEnsure & Fidelity and Ecobank & Paid & Life, Health, Disability & 2015 \\
\hline
\end{tabular}

Source: Mobile Insurance and Risk Management in Ghana. (2015). Retrieved from https://www.microfinancegateway.org/sites/default/files/publication_files/2015_mobile_insurance_risk_ assessment_update_0.pdf

BIMA, Barmore Insurance Marketing Associates; MFS, Mobile Financial Services.

also create a long-lasting client-company dyad (Morgan \& Hunt, 1994 [The Apostle Model of Customer loyalty]).

Customer Relationship Management (CRM) and Consumer Analysis are targeted at CL and, as such, it has become the fulcrum of attention among the academics and professionals within the realms of consumer service management. Theories abound, therefore, with evidence of the inextricable satisfaction-loyalty duo (Cronin \& Taylor, 1992; Lewin, Rajamma, \& Paswan, 2015). Fundamentally, CRM and Consumer Analysis encapsulate strategies adopted by managers to provide top-notch client-focused services to existing and prospective clientele, ostensibly to ignite clients' retention in general (Fornell, 1992).

Clients' loyalty is defined as 'a deeply held commitment to rebuy or re-patronise a preferred product/service consistently in the future despite situational influences and marketing efforts having the potential to cause switching behaviour' (Oliver, 1999). That is, CL connotes hanging on during trial moments; not scanning for competitors regardless of a dire situation; making an effort to communicate with the service providers in order to build on successes chalked up and also surmount possible threats. It also involves offering excellent sentimental rating scores and Word-of-Mouth (WOM) publicity. Studies, however, centre on the behaviouralattitudinal-composite trio of loyalty (Parasuraman, Zeithaml, \& Berry, 1994a; Richard \& Zhang, 2012; Wang, Ngamsiriudom, \& Hsieh, 2015; Zhang, Fu, Cai, \& Lu, 2014).

In the Apostle Model of customer loyalty, four kinds of client are distinguished - loyalists, mercenaries, defectors and hostages. It advances that a highly satisfied client will always be loyal and also be willing to serve as an apostle to a product or service offering. There is plethora of studies with empirical support that have examined the satisfaction-loyaltyperformance trio construct owing to its overarching role in consumer psychology (Helgesen, Ivar, \& Nesset, 2010; Smith \& Wright, 2004). Gremler and Brown (1996) established that CL is important for the survival of businesses; hence its antecedents ought to be explored.

Prior researchers (Adnan, Suleman, \& Bilal, 2015; Lai-Ying, Teck-Soon, Voon-Hsien, \& Keng-Boon, 2015; Thakur, 2016) opine that satisfaction is an antecedent of customer loyalty. In other words, highly satisfied clients are more likely to repurchase and become apostles of a brand. It is, however,

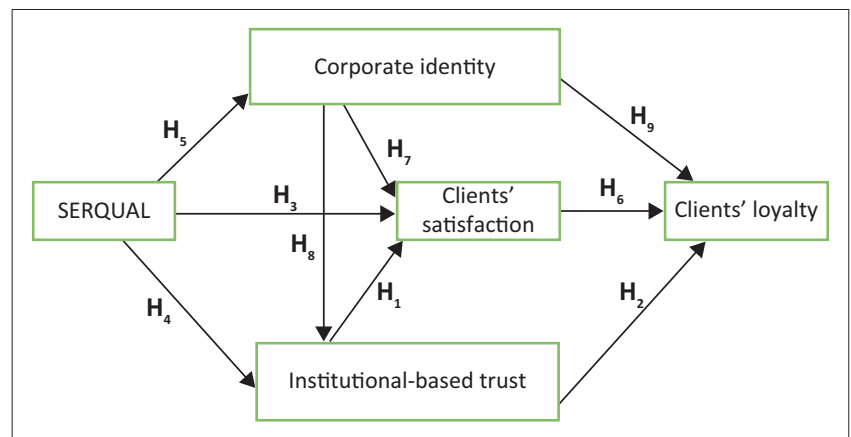

FIGURE 1: Proposed research model.

imperative to acknowledge that satisfaction is not the singular antecedent of CL. Other antecedents such as trust, value proposition, etc. have been observed to correlate positively with CL disposition (Chen \& Hu, 2012; Hartono \& Raharjo, 2015; Yieh, Chiao, \& Chiu, 2007).

This study, therefore, seeks to examine the overarching roles of institutional-based trust, Service Quality (SERQUAL), Clients' satisfaction and corporate identity and their interactions in determining $\mathrm{CL}$ within the M-insurance ecosystem (see Figure 1).

\section{Institutional-based trust}

Institutional-based trust is a form of trust that connotes the perception or the disposition of an individual relative to an institution's holistic operational structure. Institutionalbased trust theorists advance that strong institutions through cognitive, regulative and normative frameworks are able to set the tone that ultimately triggers a domino effect for permanent trust-relations among the actors of the market. Institutional-based trust is fundamentally the relationship between two entities - an individual and an institution - and it is expressed through value judgement (McKnight \& Chervany, 2002; Pavlou \& Gefen, 2004). The disposition relationship between these two parties may be negative, positive or even neutral. Therefore, in the context of this study, institutional-based trust is defined as the dynamic trust relationship between clients and service providers of the M-insurance industry. McKnight and Chervany (2002); Gefen, Karahanna, and Straub (2003); and Ratnasingham, Gefen, \& Pavlou, (2005) decomposed institutional-based trust into structural assurance (SA) and situational normality (SN) and opined that it is the antecedent of continuous service utilisation and CL. 
Structural assurance is defined as the disposition that an enabling condition (servicescape and/or experiencescape) or a congenial atmosphere that assures clients maximum security for the actualisation of their economic goals are guaranteed by the service provider. Situational normality, on the contrary, is the belief of the presence of propitious and promising structures for the success of a business, and also evidence of the assurance that systems will work normally as perceived or expected by clients. Situational normality deepens and bolsters the trust disposition of service providers (Pavlou \& Gefen, 2004). Thus, institutional-based trust is the outcome of SA and SN. In other words, SA and $\mathrm{SN}$ (as explanatory variables) complementarily translate into institutional-based trust (as the outcome or response variable).

Yang, Pang, Liu, Yen, \& Tarn (2005) posit that clients' privacy and security dispositions affect their trust relative to mobile payment systems. Thus, by extension, privacy and security contribute immensely to the institutionalbased trust in the M-insurance industry. Again, clients of M-insurance companies who perceive the presence of SA will also believe that the legal provisions relative to institutions within the M-insurance ecosystem (i.e. MNOs, insurers, TSPs and banks) work in their best interest. SA builds clients' trust and confidence, and as such makes them believe that there will always be $\mathrm{SN}$ whenever something goes haywire (Al-Ghazali, Rasli, Yusoff, \& Mutahar, 2015; Coetzee \& Eloff, 2005; Wang et al., 2015). Evidentially, inadequate privacy and security results in dissatisfaction and its antecedent customer churn (PricewaterhouseCoopers [PWC], 2014).

Zucker (1986) advances that institutional-based trust triggers a lasting relationship and continuous interactions between the market forces. Against this backdrop, institutional-based trust can impact positively on clients' satisfaction and loyalty in the M-insurance industry. We therefore postulate that:

$\mathbf{H}_{1}$ : Institutional-based trust in the M-insurance industry positively correlates with clients' satisfaction.

$\mathbf{H}_{2}$ : Institutional-based trust in the $\mathrm{M}$-insurance industry positively correlates with CL.

\section{Service quality}

Service quality (SERQUAL) is defined as a condition where a delivered service is able to meet the expectation or satisfaction of a client. In a generic perspective, it is defined as clients' overall disposition about the relative superiority or otherwise of a service provider (Edvardsson, 2005; Hubbert, 1995). Parasuraman, Zeithaml, \& Berry (1985) expressed SERQUAL as the difference between clients' perceptions $(\mathrm{P})$ and their expectations (E) about a rendered service. There is a battery of evidence that suggests that SERQUAL is the main driver and precursor of clients' satisfaction and loyalty. It anchors clients' satisfaction and sets the pace for WOM communications, while encouraging post-purchase intentions. Perceived SERQUAL creates a congenial atmosphere for the assurance of value proposition, security and trust. Thus, clients are loyal to organisations that are perceived to offer high quality services. The reverse also holds. (Zehir \& Narcıkara, 2016; Minjoon \& Serglo, 2016; Chandra, Hafni, Chandra, Purwati, \& Chandra, 2019).

Empirically, clients' satisfaction and its resultant customer loyalty as a result of perceived SERQUAL lead to an upsurge in market share through customer retention and attraction of new clients (Adnan et al., 2015; Trabelsi-Zoghlami, Berraies, \& Yahia, 2018; Acrand, Prom Tep, Brun, \& Rajaobelina, 2017; Thakur, 2016). Thus, SERQUAL dimensions are arguably one of the most researched areas in service management discipline. The SERQUAL model identified five gaps (the 5-GAP model) that cause unsuccessful service delivery. Service quality is mostly assessed through the SERQUAL model dimensions - reliability, assurance, tangibles, empathy, responsiveness (Parasuraman, Zeithaml, \& Berry, 1996; Zhou, 2013). Delivering quality service to clients is a way by which service providers inculcate trust in their clientele and it is evidenced that service providers who provide quality services are perceived to be trustworthy (Cronin \& Taylor, 1992; Kandampully \& Butler, 2001). By extension, we propose, therefore, that:

$\mathbf{H}_{3}$ : SERQUAL in the M-insurance industry positively correlates with clients' satisfaction.

$\mathbf{H}_{4}$ : SERQUAL in the M-insurance industry positively correlates with institutional-based trust.

$\mathbf{H}_{5}$ : SERQUAL positively correlates with the service providers of M-insurance corporate identity.

\section{Clients' satisfaction}

Clients' satisfaction connotes the successive disposition of clients' adoption behaviour relative to a service delivery or a product offering, expressed by a continual relationship or interactions with service providers. Oliver (1980) opines that it is the building block of post-adoption accomplishments. Other seminal studies also defined satisfaction as a person's perception - either satisfied or otherwise achieved through the comparison of a person's perceived performance of a service or with his/her expectations. Satisfied customers express it in a form of loyalty to the service providers. Conversely, dissatisfied customers refrain from future purchases and customer referrals. This adversely affects future service utility of service providers as disgruntled customers divert to other service providers (Kim, Shin, \& Lee, 2009; Suki, 2014).

Clients' satisfaction is touted, theoretically, as the result of a subjective evaluation between what is perceived and what is expected for post-purchase adoptions. Clients' satisfaction triggers post-purchase intention, positive WOM referrals, retention drive and consequently cements clients loyalty to a product or a service (Cronin \& Taylor, 1992; Parasuraman, Zeithaml, \& Berry, 1985). A myriad of studies have examined the inextricable link between satisfaction and loyalty. For instance, Peng et al. (2013) established that satisfaction is one of the main underpinning factors of client retention and 
loyalty in the Chinese mobile phone and e-commerce industry. On the basis of these assertions, we hypothesise that:

$\mathbf{H}_{\mathbf{6}}$ : Customer satisfaction in the service delivery system of the $\mathrm{M}$-insurance industry translates into CL.

\section{Corporate identity}

Corporate identity is the impression created by business entities in the 'public eye'. In other words, it is the image of the creator of one's product/service. It encompasses a collection of a multi-sensuous variables that marketing practitioners utilise as a conduit to communicate visualised information relative to branding of products or services to the consuming public. Theoretically, the fundamental goal of corporate communications is to foster and enhance strong corporate identity. It is aimed at creating and preserving corporations' identity or image (reputation) in consonance with the business's objectives, mission and vision, and also to position the brand on the mind of consumers (Ang, 2014). It rejuvenates clients' confidence and decreases their perception of risk when examining the quality and performance of a service or a product offering (Keh \& Xie, 2009).

A corporation's name and colours, product/service design, public relations, slogan, advertising, architectural design, décor, logo and physical appearance of frontline staff are some of the areas of attention whenever corporations want to create a formidable corporate identity (Dowling, 1993). The corporate identity of a firm or a corporation can only be described as strong or weak. Strong corporate identity promotes competitive advantage and fosters a bond of trust between consumers and business entities, which in turn bolsters clients' satisfaction, loyalty and improves return on investment and vice versa (Keh \& Xie, 2009; Roberts \& Dowling, 2002).

On the basis of the corporate identity of a business entity, clients are able to infer the likelihood of achieving their value proposition as assured (Chen, 2010; Hsu, Chang, Chu, \& Lee, 2014). According to Calvo-Porral and Lévy-Mangin (2015), corporate identity remains a filter that influences the operation of organisations and the perceptions of consumers are anchored on it. Several studies have espoused and garnered support for the direct link between satisfaction and corporate identity (Helm, Eggert, \& Garnefeld, 2010; He \& Lai, 2014; Keh \& Xie, 2009; Loureiro \& Kastenholz, 2011; Richard \& Zhang, 2012). We therefore, argue that:

$\mathbf{H}_{7}$ : M-insurance service providers' corporate identity correlates positively with clients' satisfaction.

$\mathbf{H}_{8}$ : M-insurance service providers' corporate identity correlates positively with institutional-based trust.

$\mathbf{H}_{\mathbf{9}}$ : M-insurance service providers' corporate identity correlates positively with CL.

The proposed research model (see Figure 1) thus sheds graphical light on both the direct and the indirect relationships among the constructs of the study.
The conceptual framework (Figure 1) consists of five constructs. Clients' loyalty is the response (dependent) variable; SERQUAL and the mediating variables (corporate identity, clients' satisfaction and institutional-based trust) serve as the independent/explanatory variables within the model. According to the model, CL within the M-insurance ecosystem is impinged upon by the collective behaviour of SERQUAL, corporate identity, clients' satisfaction and institutional-based trust, all others things being equal.

\section{Materials and methods}

This study focuses on the overarching factors of CL within the M-insurance industry with evidence from Ghana; therefore, the target population comprises clients of M-insurance in Ghana. Accordingly, a measurement instrument - a questionnaire was developed to elicit respondents' views on the constructs of study.

The questionnaire consisted of a 5-point Likert scale ranging from strongly disagree (1) to strongly agree (5) and the variables of the five-factor model, (SERQUAL, corporate identity, institutional-based trust, clients' satisfaction and Client' loyalty) were respectively coded as SEQ, COI, IBT, CSA and CLO. In order to improve content validity, scales from previous studies were adapted as the basis of measurements for each variable in our five-factor model.

The overall perceived SERQUAL metric comprised six operationalised items on SERQUAL that were intended to gauge clients' judgement on their M-insurance service provider (Brady \& Cronin, 2001; Kim, Choi, \& Lee, 2005; Parasuraman et al., 1988).

We measured satisfaction by adapting five items from the satisfaction scale described by Hubbert (1995) and Oliver (1997). Also, loyalty intentions were measured through the operationalisation of five items from Headley and Miller (1993); Parasuraman, Zeithaml and Berry (1994b); Taylor and Baker (1994), to assess continuous service utilisation. Institutional-based trust dimensions were operationalised to demonstrate clients' trust dispositions towards M-insurance service providers based on six adapted items from prior studies (McKnight, Chervany, Singh, Falcone, \& Tan, 2001; Pavlou \& Gefen, 2004; Yang et al., 2005) and lastly, five items were adapted (from Helm et al., 2010; Richard \& Zhang, 2012; Loureiro \& Kastenholz, 2011) to reflect corporate identity items (see Appendix 1).

A pre-test was initially done with five seasoned researchers to verify the face and content validity of the survey instrument; then a pilot survey was carried out with ten M-insurance clients to further validate the questionnaire instruments with regards to clarity, phrasing and duration. Eventually, a cross-sectional survey (Saunders, Lewis, \& Thornhill, 2009) was carried out and a total of 350 questionnaires were administered to the clients of the three M-insurance service providers in Accra, Ghana, in the month of February, 2018. The respondents were contacted mainly at 
the service points of these M-insurance service providers. These were clients who had come to these service points for their usual telecommunications (telco) services and were asked whether they had any M-insurance product with their telco service provider; and those who responded in the affirmative were asked to assist us in the survey.

Consistent with Saunders et al. (2009), Ndurukia et al. (2017), Giesbert and Steiner (2011), the respondents were conveniently sampled owing to the fact that there was no reliable sampling frame. From the 350 questionnaires administered, 334 (representing 94.9\%) were used for the study after the administered questionnaires were cleaned for analysis. The rest were rejected owing to serious abnormalities in the form of missing values and unengaged responses.

To check for model adequacy, reliability and validity, further screening of the data and mediation techniques were conducted after data entering to address plausible issues of data vacancies, otherwise known as missing values, skewness, kurtosis and outliers (Burne, 2004; Nunnally \& Bernstein, 1994) with the help of International Business Machines (IBM), Special Package for Social Scientists (SPSS), and Analysis of Moment Structures (AMOS) graphics.

Exploratory data analysis (EDA) was conducted as a preliminary to further analysis to obtain a cleaned pattern matrix to address problems of discriminant and convergent validity among the reflective latent variables, and also to have a deeper insight relative to the structure of the data set. Validity tests were carried out based on the Cronbach's alpha values, and factor correlation matrix. Also, confirmatory factor analysis (CFA) was conducted to further test for discriminant and convergent validity and other model fit estimates for predictive robustness of the five-factor model (Anderson \& Gerbing, 1988; Lee, 2007).

\section{Results and discussion \\ Respondents' bioinformation profile}

The sex distribution of the 334, respondents after a preliminary data analysis was found to be 192 (57.2\%) for males and $142(42.5 \%)$ for females. The respondents' age distribution was obtained as $28(8.4 \%)$ for those who were $\geq 50(8.4 \%)$, and $79(23.7 \%), 143(42.8 \%), 84 \quad(25.1 \%)$, respectively, for the age brackets ' $40-49$ ', '30-39' and '20-29' (see Table 3).

\section{Measurement model}

In order to reduce data dimensionality, and also to create suitable dimensions to address the problem of the study, EDA and CFA were conducted to test for reliability, model adequacy, convergent and/or discriminant validity of the measurement model and goodness-of-fit for model fit measurements. The $p$-value of the chi-square statistic for Bartlett's test (see Table 4$)$ was $0.000(p<0.05)$, implying that the observed variables of the five-factor model were related, and therefore, fit for factor analysis (FA).
TABLE 3: Respondents biostatistics.

\begin{tabular}{llcc}
\hline Variables & Options & Frequency & $\mathbf{\%}$ \\
\hline Gender & Male & 192 & 57.2 \\
& Female & 142 & 42.5 \\
Age & $20-29$ & 84 & 25.1 \\
& $30-39$ & 143 & 42.8 \\
& $40-49$ & 79 & 23.7 \\
& $\geq 50$ & 28 & 8.4 \\
\hline
\end{tabular}

TABLE 4: Kaiser-Meyer-Olkin measure of sampling adequacy and Bartlett's test of sphericity.

\begin{tabular}{lc}
\hline Measure or test & Value \\
\hline KMO & 0.915 \\
Bartlett's test & - \\
Chi-square & 7077.818 \\
$d f$ & 325 \\
Sig. & 0.000 \\
\hline
\end{tabular}

KMO, Kaiser-Meyer-Olkin; $d f$, degrees of freedom; Sig., significance.

TABLE 5: Pattern matrix of factor loadings.

\begin{tabular}{lccccc}
\hline Constructs & $\mathbf{1}$ & $\mathbf{2}$ & $\mathbf{3}$ & $\mathbf{4}$ & $\mathbf{5}$ \\
\hline CSA_1 & - & - & - & 0.775 & - \\
CSA_2 & - & - & - & 0.830 & - \\
CSA_3 & - & - & - & 0.911 & - \\
CSA_4 & - & - & - & 0.887 & - \\
CSA_5 & - & - & - & 0.851 & - \\
CLO_2 & - & - & - & - & 0.881 \\
CLO_3 & - & - & - & - & 0.945 \\
CLO_4 & - & - & - & - & 0.723 \\
CLO_5 & - & - & - & - & 0.690 \\
SEQ_1 & 0.714 & - & - & - & - \\
SEQ_2 & 0.905 & - & - & - & - \\
SEQ_3 & 0.873 & - & - & - & - \\
SEQ_4 & 0.906 & - & - & - & - \\
SEQ_5 & 0.808 & - & - & - & - \\
SEQ_6 & 0.720 & - & - & - & - \\
IBT_1 & - & - & 0.572 & - & - \\
IBT_2 & - & - & 0.860 & - & - \\
IBT_3 & - & - & 0.708 & - & - \\
IBT_4 & - & - & 0.653 & - & - \\
IBT_5 & - & - & 0.882 & - & - \\
IBT_6 & - & - & 0.899 & - & - \\
COI_1 & - & 0.794 & - & - & - \\
COI_2 & - & 0.833 & - & - & - \\
COI_3 & - & 0.937 & - & - & - \\
COI_4 & - & 0.954 & - & - & - \\
COI_5 & - & 0.830 & - & - & - \\
\hline CSA,c1ent & - & - & - & - & - \\
\hline
\end{tabular}

CSA, clients' satisfaction; CLO, clients' loyalty; SEQ, service quality; IBT, institutional-based trust; $\mathrm{COI}$ corporate identity.

Structural equation modelling (SEM) was conducted in order to examine the presence of causality among the variables of the five-factor model. The maximum likelihood estimation (MLE) with promax rotation was used in grouping the variables under few unrelated factors; and the robustness of our proposed model and the psychometric properties of the scale were evaluated accordingly (Kline, 2016). The FA output produced a Kaiser-Meyer-Olkin (KMO) of 0.912 (see Table 4) which exceeded the recommended threshold of $\geq 0.7$, for model adequacy (Nunnally \& Bernstein, 1994). Another indication of model adequacy can be inferred from the extraction of communalities (see Table 5). All the reflective factor loadings 
of the pattern matrix were $>0.3$ (Thompson, 2004). Model adequacy in SEM simply means how well a hypothesised model 'fit' or adequately describes the sample data.

Reliability is defined as the consistency of scores on an instrument given repeatedly to the same set of individuals (Haertel, 2006; Iacobucci \& Duchachek, 2003). It reflects the internal consistency of the entire scale measurement. Accordingly, a Cronbach's alpha point estimate for internal consistency measurement was obtained as 0.923 (see Table 6) and the deleterious effect of each item of our five-factor model exceeded the recommended threshold (> 0.7) (Finch, Immekus, \& French, 2016; Nunnally \& Bernstein, 1994).

In order to obtain greater information about the population parameter relative to internal consistency, we constructed a 95\% confidence interval (Koning \& Franses, 2003) (see Table 7). We are, therefore, $95 \%$ confident that the actual reliability of the population from which our sample was obtained is between 0.920 and 0.942 .

The validity of an instrument involves the evaluation of the extent to which obtained scores represent the intended measured traits. As evidence of the convergence validity of the five-factor model, all the factor loadings of the pattern matrix (see Table 5) were $>0.5$ and were within the recommended threshold of $\geq 0.5$. Our results also (see Figures 2 and 3) give a pictorial evidence of convergent and discriminant validity of the five-factor model. Furthermore, all the standardised regression estimates on the path diagram (see Figures 2 and 3) were above the recommended threshold of $>0.7$, affirming the convergent validity of our model (Kane, 2006; Zumbo, 2007).

The discriminant validity of our model was assessed graphically and numerically (see Figures $2-4$ and Tables 5 and 8). There were no cross-loadings among the multiindicator variables and also each of the off-diagonal values did not exceed the recommended threshold of $>0.7$ (Raykov \& Marcoulides, 2011).

The standardised estimates among the unobserved variables were all below the recommended value of $<0.8$ (Raykov \& Marcoulides, 2011) (see Figures 3 and 4). The results obtained from both the EDA and the CFA for testing model adequacy, reliability, convergent and discriminant validity overwhelmingly supported our model.

TABLE 6: Rest scores, Cronbach's alpha and explained variation of factor loadings.

\begin{tabular}{|c|c|c|c|c|c|}
\hline Constructs & Corrected item total Correlation & Cronbach's alpha if item is deleted & Communalities & Cronbach's alpha $(\alpha)$ & Percentage of variance explained \\
\hline$\overline{C S A} 1$ & 0.529 & 0.930 & 0.675 & 0.929 & 35.704 \\
\hline CSA_2 & 0.491 & 0.930 & 0.691 & - & - \\
\hline CSA_3 & 0.530 & 0.929 & 0.818 & - & - \\
\hline CSA_4 & 0.506 & 0.930 & 0.768 & - & - \\
\hline CSA_5 & 0.509 & 0.930 & 0.721 & - & - \\
\hline CLO_2 & 0.468 & 0.930 & 0.750 & 0.894 & 13.518 \\
\hline CLO_3 & 0.470 & 0.930 & 0.847 & - & - \\
\hline CLO_4 & 0.440 & 0.931 & 0.545 & - & - \\
\hline CLO_5 & 0.511 & 0.930 & 0.604 & - & - \\
\hline SEQ_1 & 0.609 & 0.928 & 0.584 & 0.929 & 9.737 \\
\hline SEQ_2 & 0.651 & 0.928 & 0.786 & - & - \\
\hline SEQ_3 & 0.660 & 0.928 & 0.754 & - & - \\
\hline SEQ_4 & 0.664 & 0.928 & 0.778 & - & - \\
\hline SEQ_5 & 0.622 & 0.928 & 0.671 & - & - \\
\hline IBT_1 & 0.519 & 0.930 & 0.503 & 0.904 & 6.121 \\
\hline IBT_2 & 0.641 & 0.928 & 0.721 & - & - \\
\hline IBT_3 & 0.608 & 0.928 & 0.581 & - & - \\
\hline IBT_4 & 0.606 & 0.928 & 0.552 & - & - \\
\hline IBT_5 & 0.607 & 0.928 & 0.726 & - & - \\
\hline IBT_6 & 0.613 & 0.928 & 0.753 & - & - \\
\hline COI_1 & 0.498 & 0.930 & 0.621 & 0.942 & 5.850 \\
\hline COI_2 & 0.623 & 0.928 & 0.779 & - & - \\
\hline COI_3 & 0.597 & 0.929 & 0.868 & - & - \\
\hline COI_4 & 0.583 & 0.929 & 0.879 & - & - \\
\hline COI_5 & 0.539 & 0.929 & 0.690 & - & - \\
\hline
\end{tabular}

Note: $\alpha$ exceeded the recommended value of 0.7 (Nunnally \& Bernstein 1994). Also, all the $\alpha$ values were significant at $p<0.001$.

CSA, clients' satisfaction; CLO, clients' loyalty; SEQ, service quality; IBT, institutional-based trust; COI corporate identity.

TABLE 7: Intraclass 95\% confidence interval F-test with true value.

\begin{tabular}{lcccccc}
\hline Variable & Intraclass correlation & Lower bound & Upper bound & $d f \mathbf{1}$ & Sig. & df $\mathbf{2}$ \\
\hline Single measures & 0.344 & 0.308 & 0.383 & 333 & 8325 \\
Average measures & 0.932 & 0.920 & 0.942 & 333 & 0.000 \\
\hline
\end{tabular}

$d f$, degrees of freedom; Sig., significance. 


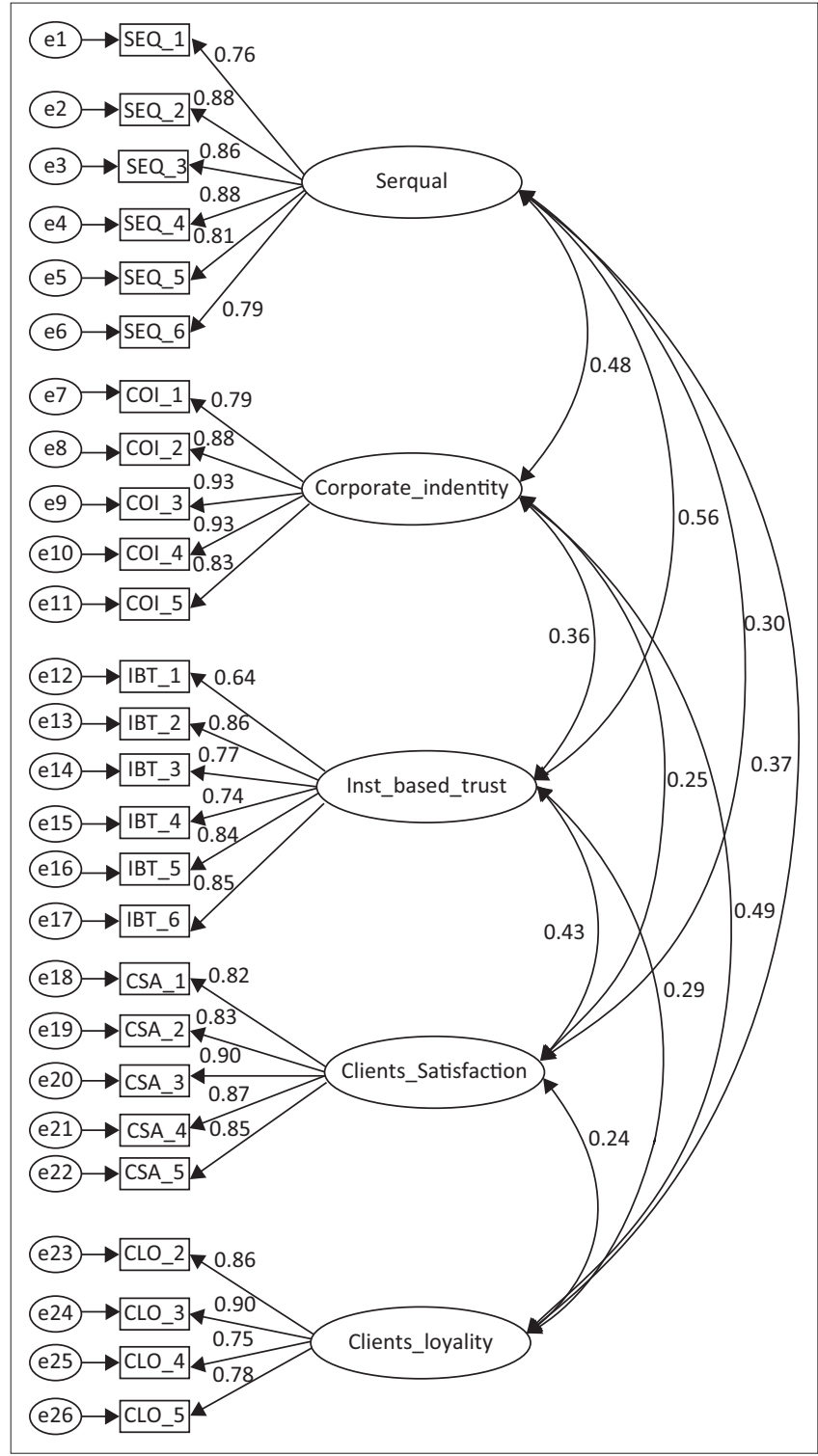

FIGURE 2: AMOS graphics output for convergent and discriminant validity.

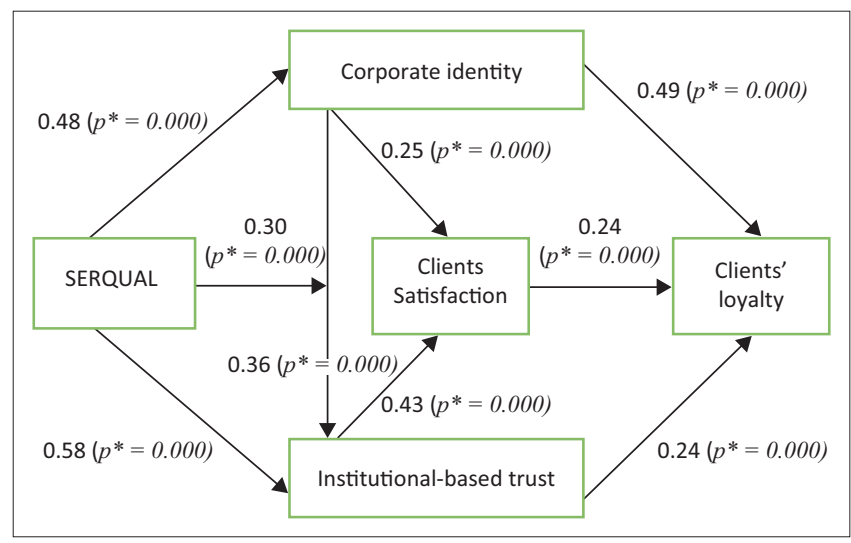

$*, p<0.001$.

SERQUAL, service quality.

FIGURE 3: Structural regression estimates from AMOS graphics.

\section{Structural model and hypothesis testing}

As empirically evidenced (Adnan et al., 2015; McKnight \& Chervany, 2002; Pavlou \& Gefen, 2004; Thakur, 2016), we found a significant positive association between institutionalbased trust and clients' satisfaction $(\beta=0.43 ; p<0.001)$; and also, a similar association was found between institutionalbased trust and CL $(\beta=0.43 ; p<0.001)$, given support for $H_{1}$ and $H_{2}$.

Again, SERQUAL was identified to have a considerable positive impact on clients' satisfaction $(\beta=0.30 ; p<0.001)$; Institutional-based trust $(\beta=0.58 ; p<0.001)$; and corporate identity $(\beta=0.43 ; p<0.001)$; as demonstrated by CalvoPorral and Lévy-Mangin (2015); Chen (2010); Hsu et al. (2014); and thus, providing support for $H_{3}, H_{4}$ and $H_{5}$. Similarly, $H_{7}, H_{8}$ and $H_{9}$ were supported because of the fact that we found corporate identity to correlate positively with clients' satisfaction $(\beta=0.25 ; p<0.001)$; institutional-based trust $(\beta=0.36 ; p<0.001)$; and CL $(\beta=0.49 ; p<0.001)$ confirming the studies conducted by Calvo-Porral and LévyMangin (2015); He and Lai (2014); Richard and Zhang (2012).

Furthermore, as espoused by prior research (TrabelsiZoghlami et al., 2018; Acrand et al., 2017; Peng et al., 2013), we found an evidence of a positive association between clients' satisfaction and CL $(\beta=0.24 ; p<0.001)$, and thus, provided support for $H_{4}$ (see Table 9 and Figures 2-4). We used eleven (11) goodness-of-fit statistics namely, $\chi^{2} / d f, p$, incremental fit index (IFI), Tucker-Lewis index (TLI), standardised root mean square residual (SRMR), goodnessof-fit index (GFI), adjusted goodness-of-fit index (AGFI), parsimony goodness-of-fit index (PGFI), comparative fit index (CFI), root mean square of approximation (RMSEA) and normed fit index (NFI) to verify whether our hypothesised model correctly fits the sampled data, and also to affirm the model's predictive robustness (see Table 10).

The chi-square value (2.149) fell within the recommended value of <3.0; RMSEA value (0.059) was within the acceptable threshold of $<0.8$; SRMR value (0.028) was within the recommended value of $<0.08$; and the GFI value $(0.873)$ was also above the recommended value of $>0.8$ (Finch et al., 2016; Lee, 2007; Thompson, 2004).

The other goodness-of-fit measures - AGFI (0.846), PGFI (0.814), CFI (0.953), IFI (0.953), NFI (0.919) and TLI (0.947) were all within the recommended thresholds $(>0.8,>0.8$, $>0.9, \geq 0.9,>0.9$ and $\geq 0.9$, respectively) (Byrne, 2001). Based on the model fit measures obtained, we can confidently conclude that the structural model correctly fits the sampled data and affirms its predictive robustness (see Table 10).

\section{Conclusion and implications}

A greater number of researches on CL regarding insurance uptake, focus principally on Western contextualisation and thus have given rise to a yawning gap and an imbalance in extant literature. On the other hand - most conspicuously in the context of developing and emerging economies, this research has not been given the attention it deserves. 


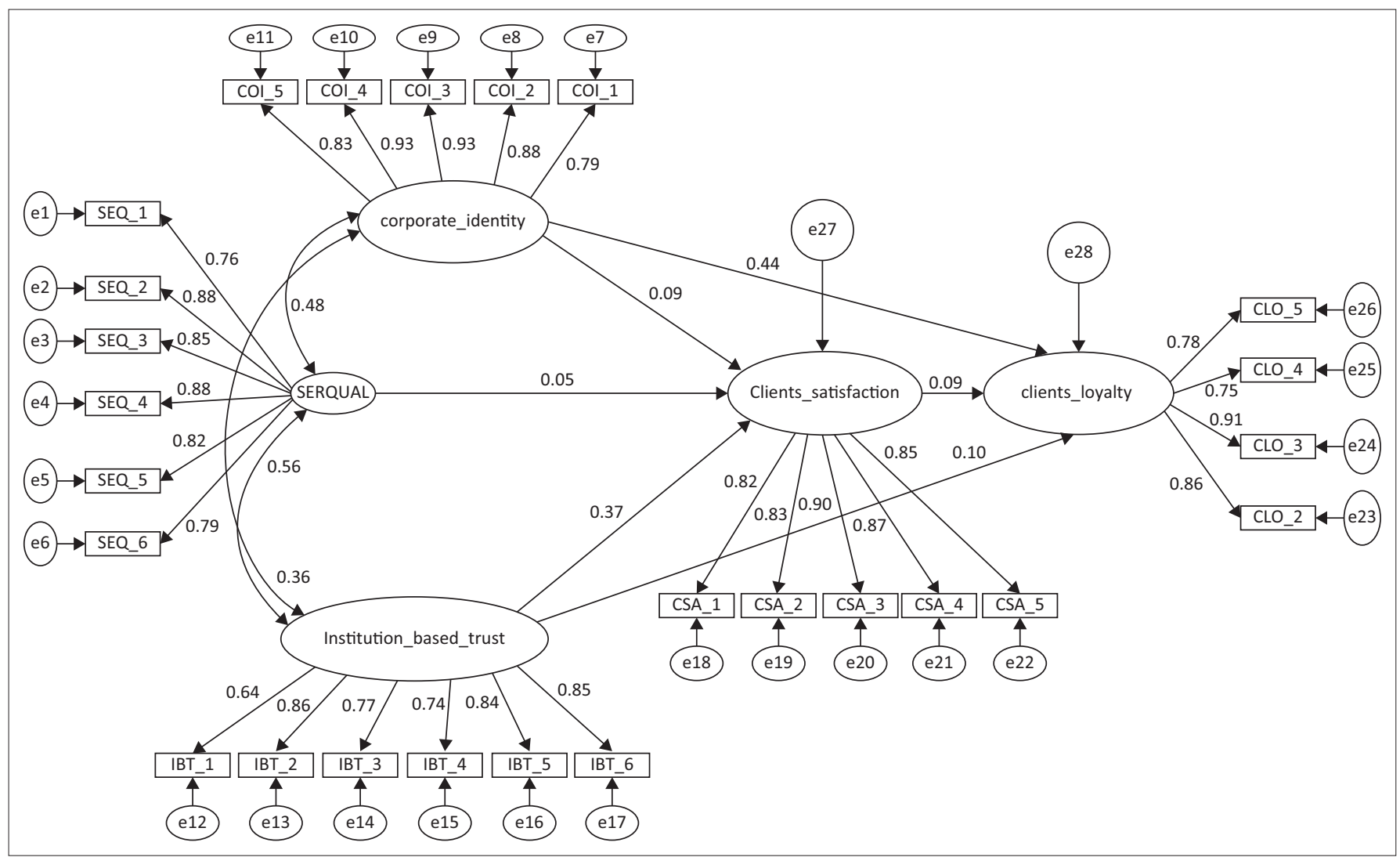

FIGURE 4: The structural model from AMOS graphics.

TABLE 8: Factor correlation matrix of factor loadings.

\begin{tabular}{lccccc}
\hline Constructs & CSA & CLO & SEQ & IBT & COI \\
\hline CSA & 1.000 & - & - & - & - \\
CLO & 0.477 & 1.000 & - & - & - \\
SEQ & 0.554 & 0.356 & 1.000 & - & - \\
IBT & 0.294 & 0.242 & 0.429 & 1.000 & - \\
COI & 0.375 & 0.493 & 0.288 & 0.249 & 1.000 \\
\hline
\end{tabular}

CSA, clients' satisfaction; CLO, clients' loyalty; SEQ, service quality; IBT, institutional-based trust; $\mathrm{COI}$ corporate identity.

By examining the overarching factors of $\mathrm{M}$-insurance $\mathrm{CL}$ in Ghana, we deepen and expand the breadth and depth of the debate on service and product loyalty within the insurance ecosystem by proffering an empirical and a theoretical view regarding the underpinning factors of $\mathrm{CL}$ in the context of developing societies. Similar to other developing countries, the M-insurance industry of Ghana is a force to reckon with, is very vibrant and, above all, contributes overwhelmingly to the general insurance uptake in the country. However, there is a dearth of knowledge about the plausible factors that shape the behavioural decisions of CL within the industry. Against this backdrop, this study addresses and broadens existing knowledge on the underlying factors that inform clients' behavioural intentions and ostensibly equips $\mathrm{M}$-insurance corporate managers with a framework and a nugget of information on clients' expectations for the assurance of their loyalty. Evidentially, a neglect of clients' expectation and a failure to have a complete understanding of their behavioural intentions catapults into a deleterious effect on CL (Thakur, 2016; Zhou, 2013).
In this study, we empirically explored the causal relationship between loyalty, SERQUAL, clients' satisfaction, institutionalbased trust and corporate identity among M-insurance clients. Consistent with other studies, we demonstrate that SERQUAL has a strong positive impact on institutionalbased trust (McKnight \& Chervany, 2002; Pavlou, Tan, \& Gefen, 2003); corporate identity (Keh \& Xie, 2009; Loureiro \& Kastenholz, 2011); and clients' satisfaction (Kim, Shin, \& Lee, 2009; Oliver, 1980; Peng et al., 2013; Suki, 2014). This implies that clients' perceptions about corporate identity, institutional-based trust and satisfaction are greatly influenced by the level of SERQUAL received from their M-insurance service providers. It further suggests that SERQUAL improvement within the M-insurance industry will trigger a halo effect on corporate identity, institutionalbased trust and clients' satisfaction.

Also, among the three constructs namely, satisfaction, institutional-based trust and corporate identity, we showed that SERQUAL has the most seminal impact on institutionalbased trust; suggesting that both pre-purchase and postpurchase behavioural decisions of clients within the $\mathrm{M}$-insurance industry are greatly influenced by the degree of institutional-based trust and confidence reposed in service providers.

Our study corroborates some pioneering research on the SERQUAL-satisfaction; corporate identity-satisfaction; institutional-based trust-satisfaction; institutional-based trust-loyalty; and the corporate identity-institutional-based 
TABLE 9: Regression path estimates.

\begin{tabular}{|c|c|c|c|c|c|c|}
\hline Hypotheses & Regression path & Standard error & Critical ratio (CR) & Estimates ( $\beta \mathrm{s})$ & $p$ & Remarks \\
\hline $\mathrm{H}_{1}$ & $\mathrm{IBT} \rightarrow \mathrm{CSA}$ & 0.028 & 6.181 & 0.43 & $0.000 *$ & Retained \\
\hline $\mathrm{H}_{2}$ & $\mathrm{IBT} \rightarrow \mathrm{CLO}$ & 0.030 & 6.950 & 0.24 & $0.000 *$ & Retained \\
\hline $\mathrm{H}_{3}$ & $\mathrm{SEQ} \rightarrow \mathrm{CSA}$ & 0.034 & 4.707 & 0.30 & $0.000 *$ & Retained \\
\hline $\mathrm{H}_{4}$ & $\mathrm{SEQ} \rightarrow \mathrm{IBT}$ & 0.028 & 5.581 & 0.58 & $0.000 *$ & Retained \\
\hline $\mathrm{H}_{5}$ & $\mathrm{SEQ} \rightarrow \mathrm{COI}$ & 0.020 & 5.335 & 0.48 & $0.000 *$ & Retained \\
\hline $\mathrm{H}_{6}$ & $\mathrm{CSA} \rightarrow \mathrm{CLO}$ & 0.026 & 4.020 & 0.24 & $0.000 *$ & Retained \\
\hline $\mathrm{H}_{8}$ & $\mathrm{COI} \rightarrow \mathrm{IBT}$ & 0.029 & 5.998 & 0.36 & $0.000 *$ & Retained \\
\hline $\mathrm{H}_{9}$ & $\mathrm{COI} \rightarrow \mathrm{CLO}$ & 0.021 & 4.427 & 0.49 & $0.000 *$ & Retained \\
\hline
\end{tabular}

Note: CSA, CLO, SEQ, IBT, and COI denotes clients' satisfaction, clients' loyalty, service quality, institutional-based trust, and corporate identity respectively. All the hypotheses were supported at a significance level of $p<0.001$.

$\mathrm{H}$, hypothesis; IBT, institutional-based trust; CSA, clients' satisfaction; SEQ, service quality; CLO, clients' loyalty; COI, corporate identity. $*, p<0.001$.

TABLE 10: Modification indices for model fit

\begin{tabular}{lccccccccccc}
\hline Goodness-of-fit & $\boldsymbol{x}^{2} / \boldsymbol{d} \boldsymbol{f}$ & $\boldsymbol{p}$ & IFI & TLI & SRMR & GFI & AGFI & PGFI & CFI & RMSEA & NFI \\
\hline CFA model & 2.149 & 0.000 & 0.953 & 0.947 & 0.028 & 0.873 & 0.846 & 0.814 & 0.953 & 0.059 & 0.915 \\
Recommended value & $<3.0$ & - & $\geq 0.9$ & $\geq 0.9$ & $<0.08$ & $>0.8$ & $>0.8$ & $>0.8$ & $>0.9$ & $<0.8$ & $>0.9$ \\
\hline
\end{tabular}

$*, p<0.001$ (two-tailed)

CFA, confirmatory factor analysis; AGFI, adjusted goodness-of-fit index; $\mathrm{CFI}$, comparative fit index; GFI, goodness-of-fit index; IFI, incremental fit index; $\mathrm{NFI}$, normed fit index; PGFI, parsimony goodness-of-fit index; RMSEA, root mean square of approximation; SRMR, standardised root mean square residual; TLI, Tucker-Lewis index; $\chi^{2} / d f$, chi-square statistics/degree-of-freedom.

trust dyads (Chen \& Hu, 2012; Loureiro \& Kastenholz, 2011). However, contrary to prior studies, we found corporate identity to correlate positively with loyalty (Aydin \& Ozer, 2005; Lai, Griffin, \& Babin, 2009).

Managerially, the empirical findings of this study will assist the industry players within the M-insurance ecosystem by equipping them with vital information pertaining to antecedents of M-insurance CL. SERQUAL, institutionalbased trust and corporate identity were established to be the striking antecedents of CL; as such, premium attention must be paid to these areas.

Owing to the unparalleled competition and the saturated market condition of the M-insurance industry, any negligence or slackness relative to SERQUAL, institutional-based trust and corporate identity will eventually set off a cascade of undesirable events. Therefore, corporate managers must develop strategies to measure and improve upon these dimensions of loyalty in order to stay afloat and remain competitive in business.

Finally, as a matter of urgency, managers must ensure that clients' satisfaction is constantly maintained because of its influential role on loyalty. Evidentially, clients are only willing to become 'apostles' and loyal to brands whenever they are highly satisfied. In this regard, managers must periodically adopt strategies that are aimed at sustaining clients' satisfaction level.

\section{Limitations and future research direction}

The study was intended to explore the motivating factors of $\mathrm{CL}$ within the M-insurance industry. It contributes to service management literature; however, it is not without limitations. Firstly, the study was cross-sectional in nature, and thus, centred on some selected M-insurance service points in
Accra, Ghana. It is, therefore, suggested that future studies should move beyond cross-sectional to longitudinal studies, and also broaden the scope of the study. Secondly, the study used the constructs - SERQUAL, institutional-based trust, corporate identity and satisfaction as the basis of examining CL. There may be other factors that impact clients' satisfaction within the M-insurance industry. Future research should seek to explore these factors.

\section{Acknowledgements}

The authors thank the National Natural Science Foundation of China (71872028) and Research Fund for the Circular Economy (XHJJ-1805 and XHJJ-1801) for supporting this research.

\section{Competing interests}

The authors have declared that no competing interests exist.

\section{Author's contributions}

E.M.A. contributed to concept development, data collection, data analysis, methodology and writing of article. J.C. contributed to concept development, methodology, supervision, editing and funding. J.F. contributed to methodology and editing.

\section{Funding}

National Natural Science Foundation of China (71872028) and Research Fund for the Circular Economy (XHJJ-1805 and XHJJ-1801).

\section{Data availability statement}

Data sharing is not applicable to this article as no new data were created or analysed in this study. 


\section{Disclaimer}

The views and opinions expressed in this article are those of the authors and do not necessarily reflect the official policy or position of any affiliated agency of the authors.

\section{References}

Acrand, M., Prom Tep, S., Brun, I., \& Rajaobelina, L. (2017). Mobile banking service quality and customer relationship. International Journal of Bank Marketing, 35(7), 1068-1089. https://doi.org/10.1108/IJBM-10-2015-0150

Adnan, A., Suleman, E., \& Bilal, T. (2015). Customer satisfaction and loyalty analysis with classification algorithms and structural equation modelling. Computers and Industry Engineering, 86, 95-106.

Al-Ghazali, B. M., Rasli, A. M., Yusoff, R. M., \& Mutahar, A. (2015). Antecedents of continuous usage intention of mobile banking services from the perspective of DeLone and McLean model of IS success. International Journal of Economics and Financial Issues 5(1), 13-21.

Anderson, J. C., \& Gerbing, D. W. (1988). Structural equation modeling in practice: A review and recommended two-step approach. Psychological Bulletin, 103(3), 411-423.

Ang, L. (2014). Principles of integrated marketing communications. New York: Cambridge University Press.

Aydin, S., \& Ozer, G. (2005). The analysis of antecedents of customer loyalty in the Turkish mobile telecommunication market. European Journal of Marketing, 39(7/8), 910-925.

Bhattacherjee, A. (2001). Understanding information systems continuance: An expectation-confirmation model. MIS Quarterly, 25(3), 351-370.

Brady, M. K., \& Cronin, J. J. (2001). Some new thoughts on conceptualizing perceived service quality: A hierarchical approach. Journal of Marketing, 65, 34-49.

Burne, B. M. (2004). Testing for multi-group invariance using AMOS araphics: A road traveled. Structural Equation Modeling, 11(2), 272-300.

Byrne, B. M. (2001). Structural equation modeling with AMOS: Basic concepts, application, and programming. Mahwah, NJ: Erlbaum.

Calvo-Porral, C., \& Lévy-Mangin, J-P. (2015). Switching behavior and customer satisfaction in mobile services: Analysing virtual and traditional operators. Computers in Human Behaviours, 49, 532-540. https://doi.org/10.1016/j. chb.2015.03.057

Chandra, T., Hafni, L., Chandra, S., Purwati, A. A., \& Chandra, J. (2019). The influence of service quality, university image on student satisfaction and student loyalty. Benchmarking: An International Journal, Emerald Publication Limited. 1463-5771. http://doi.org/10.1108/BIJ-07-2018-0212

Chen, C. F., \& Myagmarsuren, O. (2011). Brand equity, relationship quality, relationship value, and customer loyalty: Evidence from the telecommunications. Total Quality Management \& Business Excellence, 22(9), 957-974. https://doi.org/10.1080/14 783363.2011 .593872

Chen, P. T., \& Hu, H. H. (2012). The mediating role of relational benefit between service quality and customer loyalty in airline industry. Total Quality Management \& Business Excellence, 24(9), 1-12. https://doi.org/10.1080/14783363.2012.661130

Chen, Y. S. (2010). The drivers of green brand equity: Green brand image, green satisfaction, and green trust. Journal of Business Ethics, 93(2), 307-319. https:// doi.org/10.1007/s10551-009-0223-9

Chummum, Z. B. (2012). Evaluating business success in the micro insurance industry in South Africa. North-West University, Unpublished thesis.

Churchill, C. (2006). What is insurance for the poor? In C. Churchill, protecting the poor. A micro insurance compendium. Geneva: International Labour Office, ResearchGate.

Coetzee, M., \& Eloff, J. H. P. (2005). Autonomous trust for web service. Internet Research, 15(5), 493-502.

Cronin, J.J., \& Taylor, S. (1992). Measuring service quality: A re-examination and extension. Journal of Marketing, 56(3), 55-68. https://doi.org/10.2307/1252296

Dowling, G. R. (1993). Developing your company image into a corporate asset. Long Range Planning, 26(2), 101-109.

Edvardsson, B. (2005). Gurus' view: Service quality beyond cognitive assessment, passengers' behavioral intentions. Journal of Travel Research, 42(397-400).

Finch, H. W., Immekus, J. C., \& French, B. F. (2016). Applied psychometrics using SPSS and $A M O S$. Information Age Publishing Inc., Charlotte, NC.

Fornell, C. (1992). A national customer satisfaction barometer: The Swedish experience. Journal of Marketing, 56(1), 6-21. https://doi.org/10.2307/1252129

Gefen, D., Karahanna, E., \& Straub, D. W. (2003). Trust and TAM in online shopping: An integrated model. MIS Quarterly, 27(1), 51-90.

Giesbert, L., \& Steiner, S. (2011). Perceptions of (micro)insurance in Southern Ghana: The role of information and peer effects. Working paper, GIGA German Institute of Global and Area Studies. Retrieved from EconPapers.repec.org/ RePEc:zbw:gigawp:183

Giesbert, L., Steiner, S., \& Bendig, M. (2011). Participation in micro life insurance and the use of other financial services in Ghana. Journal of Risk and Insurance, 78(1), 7-35.

Gikonyo, T. C. K. (2012). The effect of mobile technology on growth of microfinance in Kenya. University of Nairobi, Nairobi, Kenya. Unpublished thesis.
Global System for Mobile Communications (GSMA). (2014). State of the industry: Mobile financial service for the unbanked. GSMA Publication. Retrieved from www.gsma.com.

Global System for Mobile Communications (GSMA). (2015). State of mobile money in Sub-Saharan Africa. GSMA Publication. Retrieved from https://www.gsma.com/ mobilefordevelopment/type/resource/2016-state-mobile-money-sub-saharanafrica.

Global System for Mobile Communications (GSMA). (2016). State of the nation report on mobile money. GSMA Publication. Retrieved from www.gsma.com

Global System for Mobile Communications (GSMA). (2017). State of the industry report on mobile money. GSMA Publication. Retrieved from www.gsma.com

Gremler, D. D., \& Brown, S.W. (1996). Service quality: Its nature, importance and implication. ResearchGate. Retrieved from https://www.researchgate.
net/publication/242451313_Service_Loyalty_Its_Nature_Importance_and net/publication/2424513
Implications/download.

Haertel, E. H. (2006). Reliability. In R. L. Brennan (Ed.), Educational measurement (4th edn.). Westport, CT: American Council on Education.

Hartono, M., \& Raharjo, H. (2015). Exploring the mediating role of affective and cognitive satisfaction on the effect of service quality on loyalty. Total Quality Management \& Business Excellence, 29(10), 971-985.

He, Y., \& Lai, K. K. (2014). The effect of corporate social responsibility on brand loyalty: The mediating role of brand image. Total Quality Management \& Business Excellence, 25(3-4), 249-263.

Headley, D. E., \& Stephen, M. J. (1993). Measuring service quality and its relationship to future consumer behavior. Marketing Health Services, 13(4), 32-42. PMID: 10131732.

Helgesen, Ø., Ivar, H. J., \& Nesset, E. (2010). Impacts of store and chain images on the 'quality -satisfaction -loyalty process' in petrol retailing. Journal of Retailing and Consumer Services, 17(2), 109-118.

Helm, S., Eggert, A., \& Garnefeld, I. (2010). Modeling the impact of corporate reputation on customer satisfaction and loyalty using partial least squares: Handbook of partial least squares. Berlin: Springer-Verlag,

Hendricks, B. (2018). The apostle model of customer loyalty. Retrieved from https:// study.com/academy/lesson/apostle-model-of-customer-loyalty-definitionexample.html.

Hsu, M. H., Chang, C. M., Chu, K. K., \& Lee, Y. J. (2014). Determinants of repurchase intention in online group-buying: The perspectives of DeLone \& McLean IS success model and trust. Computers in Human Behavior, 36, 234-245.

Hubbert, A. R. (1995). Customer co-creation of service outcomes: Effects of locus of causality attributions. Doctoral dissertation, Arizona State University, Tempe.

lacobucci, D., \& Duchachek, A. (2003). Advancing alpha: Measuring reliability with confidence. Journal of Consumer Psychology, 13, 478-487.

Kandampully, J., \& Butler, L. (2001). Service guarantees: A strategic mechanism to minimize customers' perceived risk in service organizations. Managing Service Quality, 11(1), 112-121.

Kane, M. T. (2006). Current concerns in validity theory. Journal of Educational Measurement, 38(4), 319-342.

Keh, H. T., \& Xie, Y. (2009). Corporate reputation and customer behavioral intentions: The roles of trust, identification and commitment. Industrial Marketing Management, 38(7), 732-742.

Kim, C., Choi, K., \& Lee, A. (2005). The service quality dimensions and patient's satisfaction relationships in South Korea: Comparisons across gender, age and types of service. Journal of Marketing, 19(3), 140-150.

Kim, G. Shin, B., \& Lee, H.G. (2009). Understanding dynamics between initial trust and usage intentions of mobile banking. Information System Journal, 19(3), 283-311.

Kline, R. B. (2016). Principles and practice of structural equation modeling (4th edn.). New York: The Guildford Press.

Koning, A. J., \& Franses, P. H. (2003). Confidence intervals for Cronbach's coefficient alpha values: ERIM Report Series Reference No.ER-2003-041-Mkt. Pschometrika, 65(2000), 271-280.

Lai-Ying, L., Teck-Soon, H., Voon-Hsien, L., \& Keng-Boon, O. (2015). An SEM-artificialneural-network analysis of the relationship between SERVPERF, customer satisfaction and loyalty among low-cost and full service airline. Expert System with Application, 42, 6620-6634.

Lai, F., Griffin, M., \& Babin, B. J. (2009). How quality, value, image, and satisfaction create loyalty at a Chinese telecom. Journal of Business Research, 62(10), 980-986.

Leach, J. (2010). M-insurance: The next wave of mobile financial services? Retrieved from http://www.cover.co.za/short-terminsurance/minsurance-the-next-waveof-mobile-financial-services.

Leach, J., \& Ncube, S. (2014). Regulating M-insurance in Zimbabwe: Managing risk while facilitating innovation. Financial Marketing Trust. Working Draft.

Lee, S. (2007). Structural equation modeling: A Bayesian modeling. Thousand Oaks, CA: Sage.

Lewin, J., Rajamma, R. K., \& Paswan, A. K. (2015). Customer loyalty in entertainment venues: The reality TV genre. Journal of Business Research, 68(3), 616-622. https://doi.org/10.1016/j.jbusres.2014.08.010

Loureiro, S. M. C., \& Kastenholz, E. (2011). Corporate reputation, satisfaction, delight, and loyalty towards rural lodging units in Portugal. International Journal of Hospitality Management, 30(3), 575-583.

McKnight, D. H., Chervany, N. L., Singh, M., Falcone, R., \& Tan, Y. H. (2001). Trust and distrust definitions: One bite at a time, pp. 27-54. Berlin: Springer-Verlag. https:// doi.org/10.1007/3-540-45547-7_3 
McKnight, D., \& Chervany, N. (2002). What trust means in E-Commerce customer relationships: An interdisciplinary conceptual typology. International Journal of Electronic Commerce, 6(2), 35-59.

Minjoon, J., \& Serglo, P. (2016). Examining the key dimensions of mobile banking service quality: An exploratory study. International Journal of Bank Marketing, 34(3), 307-326. https://doi.org/10.1108/IJBM-01-2015-0015

Mobile Insurance and Risk Management in Ghana. (2015). Retrieved from https:// www.microfinancegateway.org/sites/default/files/publication_files/2015 mobile_insurance_risk_assessment_update_0.pdf.

Morgan, R. M., \& Hunt, S. D. (1994). The commitment-trust theory of relationship marketing. Journal of Marketing, 54(3), 20-38. http://doi.org/10.2307/1252308

National Communication Authority (2015). Month over month mobile subscription trends. Retrieved from hht://www.nca.org.gh/40/105/Market-Share-Statistics.html.

National Insurance Commission. (2015). Landscape of microinsurance in Ghana 2015 : Supply and demand side report. NIC Publication. Retrieved from https://www. microfinancegateway.org/sites/default/files/publication_files/the_landscape of_microinsurance_in_ghana_2015_0.pdf.

Ndurukia, Z., Njeru, A. W., \& Waiganjo, E. (2017a). Factors influencing demand for micro insurance services in the insurance industry in Kenya. International Journal of Academic Research in Business and Social Sciences, 7(7), 232-259.

Ndurukia, Z., Njeru, A. W., \& Waiganjo, E. (2017b). The determinants of demand for microinsurance services in Kenya. American Journal of Finance, 2(6), 79-107.

Nunnally, J., \& Bernstein, I. (1994). Psychometric theory (3rd edn.). New York: McGraw-Hill.

Oliver, R. L. (1980). A cognitive model of the antecedents and consequences of satisfaction decisions. Journal of Marketing Research, 17(4), 460-469. http://doi org/10.2307/3150499

Oliver, R. L. (1997). Satisfaction: A behavior perspective on the consumer. New York: McGraw-Hill.

Oliver, R. L. (1999). Whence consumer loyalty? The Journal of Marketing, 63(1), 33-44. http://doi.org/10.2307/1252099

Parasuraman, A., ZeithamI V.A., \& Berry, L. L. (1985). A conceptual model of service quality and its implications for future research. Journal of Marketing, 49, 41-50. http://doi.org/10.2307/1251430

Parasuraman, A., Zeithaml, V. A., \& Berry, L. L. (1988). SERVQUAL: A multiple-item scale for measuring consumer perceptions of service quality. Journal of Retailing, 64(1), 12-37

Parasuraman, A., Zeithaml, V. A., \& Berry, L. L. (1994a). Reassessment of expectations as a comparison standard in measuring service quality: Implications for future research. Journal of Marketing, 58, 111-124.

Parasuraman, A., Zeithaml, V. A, \& Berry, L. L. (1994b). Alternative scales for measuring service quality: A comparative assessment based on psychometric and diagnostic criteria. Journal of Retailing, 70(3), 201-230. https://doi.org/10.1016/0022 4359(94)90033-7

Parasuraman, A., Zeithaml, V. A., \& Berry, L. L. (1996). A multi-item scale for measuring consumer perceptions of service quality. Journal of Retailing, $64(1), 12-40$.

Pavlou, P. A., \& Gefen, D. (2004). Building effective online marketplaces with institution-based trust. Information Systems Research, 15(1), 37-59.

Pavlou, P. A., Tan, Y. H., \& Gefen, D. (2003). The transitional role of institutional trust in online interorganizational relationships. In Proceedings of the 36th Annual Hawail International Conference on System Sciences, (pp. 10-20). IEEE.

Peng, J., Quan, J., \& Zhang, S. (2013). Mobile phone customer retention strategies and Chinese e-commerce. Electronic Commerce and Applications, 12(5), 321-327.

Prashad, P., Saunders, D., \& Aparna, D. (2013). Mobile phones and microinsurance. ILO Publication, ILO, Retrieved from http://www.microinsurancecentre.org/ resources/documents/distribution/microinsurance-paper-no-26-mobile-phonesand-microinsurance.html.

PricewaterhouseCoopers (PWC). (2014). '2014 Ghana banking survey: The future of banking in Ghana ...What's next?' Retrieved from www.pwc.com/gh/en/assets/ pdf/gh-banking-survey-2014.pdf

Ratnasingham, P., Gefen, D., \& Pavlou, P. A. (2005). The role of facilitating conditions institutional trust in electronic marketplace. Journal of Electronic Commerce in Organization, 3(2), 69-82.

Raykov, T., \& Marcoulides, G. A. (2011). Introduction to psychometric theory. New York: Routledge.

Richard, J. E., \& Zhang, A. (2012). Corporate image, loyalty, and commitment in the consumer travel industry. Journal of Marketing Management, 28(5-6) 568-593. https://doi.org/10.1080/0267257X.2010.549195
Roberts, P. W., \& Dowling, G. R. (2002). Corporate reputation and sustained superior financial performance. Strategic Management Journal, 13(12), 1077-1093. http://doi.org/10.1002/smj.274

Ronoh, D. K. (2012). The role of mobile technology in microinsurance offering in Kenya. Accra, Ghana: CIC Life Assurance Ltd. Retrieved from www.munichrefoundation. org/dms/MRS/Documents/Microinsurance/2012_LSGhana/2012LSGhana Ronoh.pdf.

Saunders, M., Lewis, P., \& Thornhill, A. (2009). Research methods for business students (5th edn.). Upper Saddle River, NJ: Pearson Education.

Smith, R. E., \& Wright, W. F. (2004). Determinants of customer loyalty and financial performance. Journal of Management Accounting Research, 16(1), 183-205. http://doi.org/10.2308/jmar.2004.16.1.183

Suki, N. M. (2014). Passenger satisfaction with airline service quality in Malaysia: A structural equation modelling approach. Research in Transportation Business and Management, 10, 26-32. http://doi.org/10.1016/j.rtbm.2014.04.001

Taylor, S. A., \& Baker, L. T. (1994). An assessment of the relationship between service quality and customer satisfaction in the formation of customers' purchase intentions. Journal of Retailing, 70(2), 163-178. http://doi.org/10.1016/00224359(94)90013-2

Tellez, C. (2013). Emerging practices in mobile microinsurance. Retrieved from https://www.gsma.com/mobilefordevelopment/wp-content/uploads/2012/07/ MMU_m-insurance-Paper_Interactive-Final.pdf.

Tellez, C., \& Zetterli, P. (2012). The emerging global landscape of mobile microinsurance. Retrieved from https://www.cgap.org/sites/default/files/Brief-The-EmergingGlobal-Landscape-of-Mobile-Microinsurance-Jan-2014.pdf.

Thakur, R. (2016). Understanding customer engagement and loyalty: A case of mobile device for shopping. Journal of Retailing and Customer Services, 32, 151-163.

Thompson, B. (2004). Exploratory and confirmatory factor analysis. Washington, DC: American Psychological Association. http://doi.org/10.1037/10694-000

Trabelsi-Zoghlami, A., Berraies S., \& Yahia, K. B. (2018). Service quality in mobilebanking-application context: Do users' age and gender matter. Total Quality Management and Business Excellence, 1-30. https://doi.org/10.1080/14783363 .2018.1492874

Tran, M. (2013). Ghana mobile firms offer free insurance to keep customers hanging on. Retrieved from https://www.theguardian.com/global-development/2013/ may/02/ghana-mobile-free-insurance.

Vatanasombut, B., Igbaria, M., Stylianou, A. C., \& Rodgers, W. (2008). Information systems continuance intention of web-based applications customers: The case of online banking. Information and Management, 45(7), 419-428. http://doi. of online banking. Information
org/10.1016/j.im.2008.03.005

Wang, S. W. Ngamsiriudom, W., \& Hsieh, C. (2015). Trust disposition, trust antecedents, trust, and behavioral intention. The Service Industries Journal, 35(10), 555-572. http://doi.org/10.1080/02642069.2015

Yang, Q., Pang, C., Liu, L., Yen, D. C., \& Tarn, J. (2005). Exploring consumer perceived risk and trust for online payments: An empirical study in China's younger generation. Computers in Human Behavior, 50, 9-24. http://doi.org/10.1016/j. chb.2015.03.058

Yieh, K., Chiao, Y., \& Chiu, Y. (2007). Understanding the antecedents to customer loyalty by applying structural equation modeling. Total Quality Management \& Business Excellence, 18(3), 267-284. https://doi.org/10.1080/ Management \& Business

Zehir, C., \& Narcıkara, E. (2016). E-service quality and e-recovery service quality: Effects on value perception and loyalty intentions. Procedia-Social Behavioral Sciences, 229, 427-443. https://doi.org/10.1016/j.sbspro.2016.07.153

Zetterli, P. (2013). Can phones drive insurance markets? Initial results from Ghana, Working Paper. Washington, DC. Unpublished working paper.

Zhang, H., Fu, X., Cai, L. A., \& Lu, L. (2014). Destination image and tourist loyalty: A meta-analysis. Tourism Management, 40, 213-223. http://doi.org/10.1016/j. tourman.2013.06.006

Zhou, T. (2013). An empirical examination of continuance intention of mobile payment services. Decision Support Systems, 54(2), 1085-1091. http://doi.org/10.1016/j. dss.2012.10.034

Zucker, L. G. (1986). Production of trust: Institutional sources of economic structure, 1840 to 1920 . In B. M. Slaw \& L. L. Cummlngs (Eds.), Research in organizationa behavior (pp. 53-112). Greenwich, CT: JAI Press.

Zumbo, B. D. (2007). Validity: Foundational issues and statistical methodology. In C. R. Rao \& S. Sinharay (Eds.), Handbook of statistics Psychometrics (Vol. 26, pp. 45-57) Amsterdam: Elsevier Science B.V. 


\section{Appendix 1}

Corporate identity: Adapted from Helm et al. (2010); Richard and Zhang (2012); Loureiro and Kastenholz (2011):

- COI_1: My M-insurance service provider has a unique niche in terms of product offering.

- COI_2: My M-insurance service provider is well established and the most popular for reliable insurance provision.

- COI_3: My M-insurance service provider has an outstanding public identity.

- COI_4: My M-insurance service provider is popular for its corporate social responsibilities.

- COI_5: My M-insurance service provider is innovative and is known for operating a propitious business model.

SERQUAL: Adapted from Kim et al. (2005); Brady and Cronin (2001); Parasuraman et al. (1988):

- SEQ_1: Premium payment meets my expectations.

- SEQ_2: Claims are paid promptly.

- SEQ_3: Premiums are paid at my convenience.

- SEQ_4: My M-insurance service provider has the best customer care services.

- SEQ_5: Clients' problems are swiftly addressed with dedication by my M-insurance service provider.

- SEQ_6: My M-insurance service provider is efficient and knowledgeable in its insurance offering.

Clients' satisfaction: Adapted from Hubbert (1995); Oliver (1997):

- CSA_1: I am very satisfied with how my M-insurance service provider handles clients.

- CSA_2: I am highly satisfied with the general office atmosphere of my M-insurance provider.

- CSA_3: I am highly satisfied with the insurance products offered by my M-insurance provider.

- CSA_4: I am highly satisfied with the premium and claim payments of my M-insurance provider.

- CSA_5: Overall, I am very satisfied with service rendered by my M-insurance provider.

Institutional-based trust: Pavlou and Gefen (2004); McKnight et al. (2001); Yang et al. (2005):

- IBT_1: I highly trust my M-insurance service provider.

- IBT_2: My M-insurance service provider is reliable and delivers on its value proposition.

- IBT_3: I trust the premium and claim payment system of my M-insurance service provider.

- IBT_4: I am highly confident that my M-insurance service will not act contrary to its promises.

- IBT_5: My M-insurance service provider is legally registered and operates in the interest of clients.

- IBT_6: My M-insurance service provider is widely known for fulfilling its responsibilities and commitments.

Clients' loyalty: Adapted from Headley and Miller (1993); Zeithaml et al. (1994); Taylor and Baker (1994):

- CLO_1: I shall forever remain an apostle of my M-insurance service provider.

- CLO_2: I shall continue to engage the services of my M-insurance provider.

- CLO_3: I shall always recommend the services of my M-insurance provider to others.

- CLO_4: I shall be with my M-insurance service provider unconditionally.

- CLO_5: I shall proffer solutions to my M-insurance provider during challenging moments.

Note: Corporate identity, SERQUAL, clients' satisfaction, institutional-based trust, and clients' loyalty were respectively coded as COI, SEQ, CSA, IBT, and CLO for the measurement of the constructs and items. 